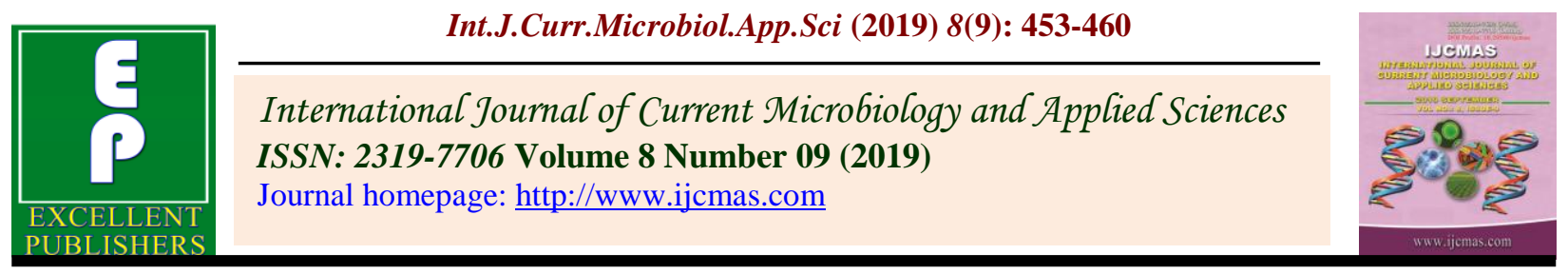

Original Research Article

https://doi.org/10.20546/ijcmas.2019.809.055

\title{
Cost and Returns of Coffee Cultivation in Visakhapatnam District of Andhra Pradesh, India
}

\author{
C.H. Satish Kumar ${ }^{1 *}$, K. Solmon Raju Paul ${ }^{1}$, K. Umadevi ${ }^{1}$ and S.K.N. Umar ${ }^{2}$ \\ ${ }^{1}$ Department of Agricultural Economics, ${ }^{2}$ Department of Statistics and Computer Application, \\ Agricultural College, Bapatla, ANGRAU, 522 101, India \\ *Corresponding author
}

\begin{tabular}{|l|}
\hline Ke y w o r d s \\
Coffee, Cost and \\
returns, BCR, IRR \\
\hline Article Info \\
\hline $\begin{array}{l}\text { Accepted: } \\
\text { 04 August } 2019 \\
\text { Available Online: } \\
\text { 10 September 2019 }\end{array}$ \\
\hline
\end{tabular}

\section{Introduction}

In India Coffee is largely grown in the southern states like Karnataka $(70.00 \%)$, Kerala (20.00\%), Tamil Nadu (7.00\%) and non-traditional areas (Andhra Pradesh and Odisha. Over 98.00 per cent of coffee holdings and 70.00 per cent of coffee production in India is by small holders. About 77.00 per cent of holdings are classified as
The paper highlights cost and returns of coffee growing by tribal farmers at Paderu division in Visakhapatnam district of Andhra Pradesh.Data collection was done using pre tested questionnaire administrated on 90 coffee producers selected randomly. According to the study small scale traditional farms had negligible fixed costs. So we have not taken the fixed costs in computation of cost of cultivation of coffee in the present study. The gross margin analysis indicates average total variable cost of coffee was Rs.27644 per ha, average gross returns per ha obtained by selling the fresh fruit berry was Rs. 84550 average gross margin was Rs.56876.17 per ha and profitability index was 2.05 indicating that the farmer earned Rs.2.05 on each rupee invested. The capital costs were found to be much lower in the study area. Amortized cost and returns of coffee plantation revealed that the anticipated marginal net revenue was more than amortized net revenue indicating that it is profitable to continue with the existing plantation.Farm investment techniques like net present value, BCR, IRR and payback period were computed and found to be Rs.243136, 2.03, 26.39 and 9 years respectively which pointed out that the investment on coffee plantation was feasible and economically viable. For instance use of machinery was almost nil indicating no costs involved in carrying out operations. In other words, the tribal farmers were saved from incurring maintenance and fuel costs for machines. 
Agricultural activity in Paderuregion is mostly seasonal, which provide only seasonal employment to them and have to sit idle for the rest of the season. These tribes are habituated for shifting cultivation, which is locally mown as the 'Poducultivation. Podu' cultivation practiced by the tribal growers resulted in extensive denudation of forest cover and enormous soil erosion causing siltation of the river basins. To check podu' cultivation and to improve socio-economic status of tribal inhabitants through sustainable farming, coffee cultivation was found to be the best option as it is suitable for cultivation in hilly slopes under the shade of forest cover (Indian coffee, 2015).

Coffee was perennial and labor intensive plantation crop (Deepika and Jyotishi, 2013). Coffee cultivation has an enormous potential to income generation opportunities in Paderu region, because coffee has high demand in International market. Coffee is high value low volume cash crop which is nearly three times more profitable as compared to cash crops and five times than other cereal crops (Bajracharya, 2003). Farmers are not properly and adequately aware of coffee farming technologies. Coffee plantations were located in hilly slopes that lead less scope for mechanization and transporting facilities. Coffee plantation requires initially more expenditure for establishment of plantations, in this region growers are small size holders of plantations and they mostly depends on human labour and mechanization was negligible. With these conditions the main aim of the study was to examine cost and returns of coffee production.

\section{Materials and Methods}

The study was conducted in Andhra Pradesh during the year 2016-17. Multistage random sampling design was used for the study. Paderu division was purposively selected as coffee is extensively cultivated in this division. This division occupies first place both in area and production in Visakhapatnam district. Six mandals namely G. K. Veedhi, Chintapalli, G. Madugula, Paderu, Hukumpeta and Dumriguda were purposively selected as they occupy the first six positions in area under coffee. Three villages from each mandal were selected based on highest area under coffee plantation. The coffee growing tribal farmers of the selected villages were listed in each village along with their operational holding and arranged in descending order and five coffee growing tribal farmers were randomly selected to make a sample of 90 respondents for the study. Face to face interview was conducted to fill up the semi structured interview schedule. Focus group discussions were conducted and key informant survey was carried out and secondary data were collected from different sources.

\section{Gross margin analysis}

Gross margin is the difference between gross returns and total variable costs. It is a useful planning tool in situation where fixed capital is a negligible portion of the farming enterprise in case of small scale subsistence agriculture (Erhaborand Olukosi, 1988.)

Gross Margin $=$ Gross Returns - Total Variable Cost

Gross Returns $=$ Price of Fresh Fruit Berry (Rs. $/ \mathrm{kg}$ ) x Total Yield

Total Variable Cost $=$ Summation of costs on all variable inputs

Profitability index $=$ Net Income $/$ Total Variable Cost

\section{Results and Discussion}

Coffee is one of the most important commercial crops grown in the study area. Coffee cultivation is highly labour intensive. The operations like weed control (thrice in a 
year), upturning the soil (twice a year), application of manures and fertilizers (twice a year), pruning (twice a year), application of pesticides and insecticides (once a year) and coffee beans collection through hand picking (thrice a year), and all these activities are done annually to rear, nurture and maintain coffee plants in order to obtain the maximum possible yield from them. Expenses incurred for these activities are termed as current expenses.

\section{Cost of cultivation of coffee}

The total cost which a farmer incurs on his farm includes two types of costs viz., fixed costs and variable costs. Fixed costs represent farming expenses of overhead nature which do not vary with output. These expenses must be paid even if nothing is produced. Variable expenses are those expenses which do vary with output and are employed differently for various farm operations. This could be the cost of planting which includes jungle clearing and preparation of stakes, line marking, opening and closing of pits, planting, seedling, fertilizer, irrigation and harvesting etc.

In the study area, majority of tribal farmers grow coffee organically by default, the cost incurred on pesticides was nominal. Irrigation cost was also minimum as the crop raised is under rainfed conditions. Seedlings were supplied by ITDA at subsidized rates.

The capital costs were found to be much lower in the study area. For instance use of machinery was almost nil indicating no costs involved in carrying out operations. In other words, the tribal farmers were saved from incurring maintenance and fuel costs for machines. Moreover location of crops in the hilly area acted as barrier for tractor in carrying out the operations thus offsetting the huge capital costs. According to the study by Erhabor and Olukosi (1988) small scale traditional farms had negligible fixed costs. So we have not taken the fixed costs in computation of cost of cultivation of coffee in the present study. The summary chart of cost and benefits was prepared through the spread sheet model. The variable costs of coffee cultivation over a period of 25 years was presented in appendix-I

\section{Cost and returns of coffee}

According to the study by Noormahayu et al., (2009), cost and returns of coffee in study area calculated from the spread sheet model over a period of 25 years are presented in Table 1. The table reveals that maximum cost incurred first year because of establishment cost incurred in bush clearance, line marking, digging of pits, and planting the coffee seedlings. There is no revenue during the first three years because the coffee starts producing from fourth year. Revenue starts to climb steeply from fifth year and continue to increase annually until $15^{\text {th }}$ year after which it begins to decline due to the age of plant. The initial average yield was $228.16 \mathrm{~kg} / \mathrm{ha}$. The yield increases and reaches a peak in the $15^{\text {th }}$ year with a peak average yield of $4960.00 \mathrm{~kg} / \mathrm{ha}$ after which it declines. This shows that the yield of coffee is affected by law of diminishing returns. It also indicates that, for the first four years, farmers were found to be operating in the loss. The $9^{\text {th }}$ year was found to be the shortest payback period for coffee farming. These findings was similar in line of Poudel et al.,(2009).

\section{Cost of production}

In the present study, only variable cost items were included for analyzing the cost of coffee production. The variable costs included were cost of seedling, cost of labor, cost of manure, cost of plant protection, cost of irrigation and cost of harvesting. Gross margin, profitability index and benefit cost analysis of coffee production was presented in Table 2 . 
Table.1 Cost and returns of coffee (per hectare)

\begin{tabular}{|c|c|c|c|c|}
\hline $\begin{array}{c}\text { Age of } \\
\operatorname{garden}(\text { years })\end{array}$ & $\begin{array}{c}\text { Total variable } \\
\text { cost } \\
\text { (Rs.) }\end{array}$ & $\begin{array}{l}\text { Yield of coffee } \\
\text { (FFB) (kg) }\end{array}$ & $\begin{array}{l}\text { Gross Returns } \\
\text { (Rs.) }\end{array}$ & $\begin{array}{l}\text { Net returns } \\
\text { (Rs.) }\end{array}$ \\
\hline 1 & 65308.32 & 0.00 & 0.00 & -65308.32 \\
\hline 2 & 14666.72 & 0.00 & 0.00 & -14666.72 \\
\hline 3 & 17918.00 & 0.00 & 0.00 & -17918.00 \\
\hline 4 & 21124.64 & 228.16 & 6844.80 & -14279.84 \\
\hline 5 & 21762.00 & 1711.20 & 51336.00 & 29574.00 \\
\hline 6 & 23044.16 & 2157.60 & 64728.00 & 41683.84 \\
\hline 7 & 23371.52 & 2157.60 & 64728.00 & 41356.48 \\
\hline 8 & 24366.00 & 2263.62 & 67908.60 & 43542.60 \\
\hline 9 & 24993.44 & 2489.92 & 74697.60 & 49704.16 \\
\hline 10 & 25630.80 & 2793.72 & 83811.60 & 58180.80 \\
\hline 11 & 26268.16 & 2933.84 & 88015.20 & 61747.04 \\
\hline 12 & 26622.80 & 2997.08 & 89912.40 & 63289.60 \\
\hline 13 & 27250.24 & 3429.84 & 102895.20 & 75644.96 \\
\hline 14 & 27565.20 & 4464.00 & 133920.00 & 106354.80 \\
\hline 15 & 27880.16 & 4960.00 & 148800.00 & 120919.84 \\
\hline 16 & 31753.92 & 4960.00 & 148800.00 & 117046.08 \\
\hline 17 & 30814.00 & 4588.00 & 137640.00 & 106826.00 \\
\hline 18 & 30474.24 & 4538.40 & 136152.00 & 105677.76 \\
\hline 19 & 30466.80 & 3968.00 & 119040.00 & 88573.20 \\
\hline 20 & 29169.76 & 3945.68 & 118370.40 & 89200.64 \\
\hline 21 & 28862.24 & 3390.16 & 101704.80 & 72842.56 \\
\hline 22 & 28854.80 & 3377.76 & 101332.80 & 72478.00 \\
\hline 23 & 28202.56 & 3298.40 & 98952.00 & 70749.44 \\
\hline 24 & 27912.40 & 3184.32 & 95529.60 & 67617.20 \\
\hline 25 & 27572.64 & 2621.36 & 78640.80 & 51068.16 \\
\hline
\end{tabular}

Table.2 Gross margin, profitability index and benefit cost ratio of coffee (per ha)

\begin{tabular}{|c|l|c|c|}
\hline S. No. & \multicolumn{1}{|c|}{ Particulars } & Units & Average \\
\hline $\mathbf{1}$ & Total variable cost & Rs. & 27674.22 \\
\hline $\mathbf{2}$ & Yield(FFB) & $\mathrm{kg}$ & 2818.35 \\
\hline $\mathbf{3}$ & Price(FFB) & Rs. & 30.00 \\
\hline $\mathbf{4}$ & Total return & Rs. & 84550.39 \\
\hline $\mathbf{5}$ & Cost of production & Rs. Per kg & 9.82 \\
\hline $\mathbf{6}$ & Gross margin & Rs. & 56876.17 \\
\hline $\mathbf{7}$ & Benefit Cost Ratio & & 3.05 \\
\hline $\mathbf{8}$ & Profitability index & & 2.05 \\
\hline
\end{tabular}


Table.3 Amortized cost and returns of coffee

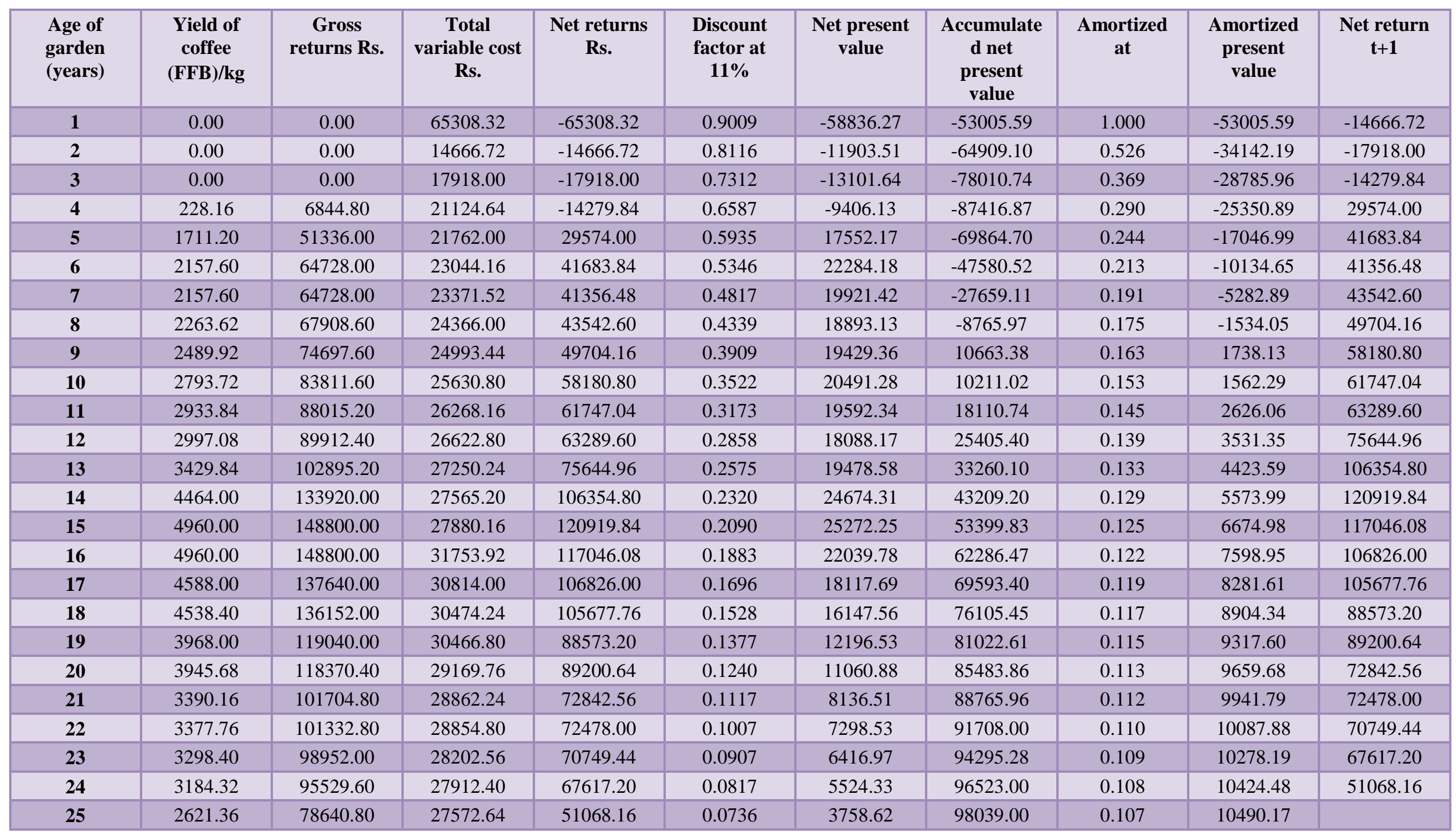


Appendix.I Variable cost of coffee cultivation (year-wise) of sample farmers

\begin{tabular}{|c|c|c|c|c|c|c|c|c|c|c|c|c|c|c|c|c|c|c|c|}
\hline $\begin{array}{l}\text { Age of } \\
\text { garden } \\
\text { (years) }\end{array}$ & $\begin{array}{c}\text { Bush } \\
\text { clearance }\end{array}$ & $\begin{array}{c}\text { Bench } \\
\text { terracing }\end{array}$ & $\begin{array}{c}\text { Line } \\
\text { Marking }\end{array}$ & $\begin{array}{c}\text { Digging of } \\
\text { pits }\end{array}$ & Seedlings & $\begin{array}{l}\text { Mixed } \\
\text { plants }\end{array}$ & $\begin{array}{c}\text { Transport } \\
\text { of plant } \\
\text { material }\end{array}$ & Planting & $\begin{array}{c}\text { manures } \\
\text { \&fertilizers }\end{array}$ & Staking & Fire path & $\begin{array}{l}\text { Planting } \\
\text { of Live } \\
\text { fence, }\end{array}$ & $\begin{array}{c}\text { Irriga } \\
\text { tion }\end{array}$ & $\begin{array}{c}\text { Shade } \\
\text { regu } \\
\text { lation }\end{array}$ & $\begin{array}{c}\text { Handling } \\
\text { \&Desuckering }\end{array}$ & $\begin{array}{c}\text { Weeding } \\
\text { \& topping }\end{array}$ & $\begin{array}{l}\text { protection } \\
\text { Chemicals }\end{array}$ & Harvesting & $\begin{array}{c}\text { Total } \\
\text { variable } \\
\text { cost }\end{array}$ \\
\hline 1 & 4605.36 & 13463.92 & 1064.02 & 24090.84 & 3010.89 & 225.70 & 4605.38 & 2480.00 & 2480.00 & 213.28 & 1063.92 & 1416.08 & 5314.69 & 0.00 & 0.00 & 1274.22 & 0.00 & 0.00 & 65308.32 \\
\hline 2 & 00 & 0.00 & .00 & 224.00 & 1488.00 & 0.00 & 992.00 & 592.15 & 5323.73 & 0.00 & 0.00 & 0.00 & 0.00 & 0.00 & 0.00 & 3046.84 & 0.00 & 0.00 & 14666.72 \\
\hline 3 & 0.00 & 0.00 & 0.00 & 3554.67 & 1674.00 & 0.00 & 1066.40 & 639.84 & 6944.00 & 0.00 & 0.00 & 0.00 & 0.00 & 0.00 & 0.00 & 4039.09 & 0.00 & 0.00 & 17918.00 \\
\hline 4 & 0.00 & 0.00 & 0.00 & 3348.00 & 1488.00 & 0.00 & 1016.80 & 610.08 & 5911.82 & 0.00 & 0.00 & 0.00 & 0.00 & 0.00 & 2678.40 & 4290.40 & 180.54 & 1600.59 & 21124.64 \\
\hline 5 & 0.00 & 0.00 & 0.00 & 1785.60 & 1011.84 & 0.00 & 694.40 & 405.27 & 4984.80 & 0.00 & 0.00 & 0.00 & 0.00 & 0.00 & 3559.60 & 4999.00 & 187.49 & 4134.00 & 21762.00 \\
\hline 6 & 0.00 & 0.00 & 0.00 & 1736.88 & 997.41 & 0.00 & 694.40 & 399.45 & 4444.16 & 0.00 & 0.00 & 0.00 & 0.00 & 0.00 & 3953.99 & 5125.33 & 187.50 & 5505.04 & 23044.16 \\
\hline 7 & 0.00 & 0.00 & 0.00 & 1711.95 & 868.00 & 0.00 & 687.46 & 347.20 & 1414.84 & 0.00 & 0.00 & 0.00 & 0.00 & 0.00 & 4794.67 & 5329.08 & 187.49 & 8030.84 & 23371.52 \\
\hline 8 & 0.00 & 0.00 & 0.00 & 930.00 & 465.00 & 0.00 & 364.56 & 186.00 & 939.92 & 0.00 & 0.00 & 0.00 & 0.00 & 0.00 & 4919.82 & 5864.21 & 220.97 & 10475.52 & 24366.00 \\
\hline 9 & 0.00 & 0.00 & 0.00 & 913.26 & 457.56 & 0.00 & 360.84 & 184.14 & 1068.88 & 0.00 & 0.00 & 0.00 & 0.00 & 33.07 & 4680.77 & 6448.00 & 225.68 & 10621.24 & 24993.44 \\
\hline 10 & 0.00 & 0.00 & 0.00 & 890.94 & 453.84 & 0.00 & 360.84 & 178.56 & 1068.88 & 0.00 & 0.00 & 0.00 & 0.00 & 33.07 & 3804.44 & 6751.11 & 223.20 & 11865.92 & 25630.80 \\
\hline 11 & 0.00 & 0.00 & 0.00 & 694.90 & 355.63 & 0.00 & 285.70 & 138.38 & 1116.00 & 0.00 & 0.00 & 0.00 & 0.00 & 33.54 & 3830.48 & 7515.14 & 229.41 & 12068.98 & 26268.16 \\
\hline 12 & 0.00 & 0.00 & 0.00 & 570.15 & 321.90 & 0.00 & 260.65 & 122.76 & 796.25 & 0.00 & 0.00 & 0.00 & 0.00 & 35.43 & 3880.47 & 7611.69 & 229.40 & 12794.09 & 26622.80 \\
\hline 13 & 0.00 & 0.00 & 0.00 & 556.30 & 319.18 & 0.00 & 260.52 & 114.58 & 762.60 & 0.00 & 0.00 & 0.00 & 0.00 & 38.94 & 4506.16 & 7702.88 & 235.09 & 12754.00 & 27250.24 \\
\hline 14 & 0.00 & 0.00 & 0.00 & 496.00 & 288.92 & 0.00 & 248.00 & 101.15 & 1192.58 & 0.00 & 0.00 & 0.00 & 0.00 & 41.80 & 4513.60 & 7707.84 & 223.20 & 12752.11 & 27565.20 \\
\hline 15 & 0.00 & 0.00 & 0.00 & 496.00 & 287.68 & 0.00 & 248.00 & 100.44 & 1507.84 & 0.00 & 0.00 & 0.00 & 0.00 & 42.41 & 4513.60 & 7707.84 & 223.20 & 12753.15 & 27880.16 \\
\hline 16 & 0.00 & 0.00 & 0.00 & 641.70 & 285.20 & 0.00 & 345.96 & 132.86 & 1969.12 & 0.00 & 0.00 & 0.00 & 0.00 & 49.60 & 5017.04 & 8990.00 & 143.84 & 14178.60 & 31753.92 \\
\hline 17 & 0.00 & 0.00 & 0.00 & 620.00 & 409.20 & 0.00 & 345.96 & 128.34 & 2048.48 & 0.00 & 0.00 & 0.00 & 0.00 & 53.32 & 5039.36 & 8835.00 & 148.34 & 13186.00 & 30814.00 \\
\hline 18 & 0.00 & 0.00 & 0.00 & 582.18 & 409.20 & 0.00 & 345.96 & 124.00 & 2068.32 & 0.00 & 0.00 & 0.00 & 0.00 & 61.05 & 5783.36 & 8869.00 & 161.17 & 12070.00 & 30474.24 \\
\hline 19 & 0.00 & 0.00 & 0.00 & 523.56 & 409.20 & 0.00 & 337.53 & 116.81 & 2088.16 & 0.00 & 0.00 & 0.00 & 0.00 & 64.73 & 6004.08 & 9151.20 & 183.52 & 11588.02 & 30466.80 \\
\hline 20 & 0.00 & 0.00 & 0.00 & 496.25 & 389.61 & 0.00 & 334.80 & 104.71 & 2125.71 & 0.00 & 0.00 & 0.00 & 0.00 & 68.08 & 6513.31 & 9027.20 & 354.00 & 9756.09 & 29169.76 \\
\hline 21 & 0.00 & 0.00 & 0.00 & 437.65 & 388.74 & 0.00 & 331.08 & 98.58 & 2227.04 & 0.00 & 0.00 & 0.00 & 0.00 & 79.86 & 6611.68 & 9424.00 & 372.00 & 8891.62 & 28862.24 \\
\hline 22 & 0.00 & 0.00 & 0.00 & 429.23 & 386.88 & 0.00 & 323.64 & 87.53 & 2388.15 & 0.00 & 0.00 & 0.00 & 0.00 & 85.81 & 6834.52 & 8525.55 & 389.36 & 9404.14 & 28854.80 \\
\hline 23 & 0.00 & 0.00 & 0.00 & 409.20 & 379.29 & 0.00 & 310.62 & 85.85 & 2480.00 & 0.00 & 0.00 & 0.00 & 0.00 & 87.53 & 6944.00 & 7547.83 & 398.04 & 9560.20 & 28202.56 \\
\hline 24 & 0.00 & 0.00 & 0.00 & 372.00 & 377.58 & 0.00 & 302.56 & 74.40 & 2579.20 & 0.00 & 0.00 & 0.00 & 0.00 & 91.85 & 7936.00 & 6281.84 & 406.72 & 9490.25 & 27912.40 \\
\hline 25 & 0.00 & 0.00 & 0.00 & 438.96 & 438.96 & 0.00 & 297.60 & 93.00 & 2788.90 & 0.00 & 0.00 & 0.00 & 0.00 & 248.00 & 7936.00 & 6130.56 & 317.44 & 8883.22 & 27572.64 \\
\hline
\end{tabular}


It can be observed from table 2 that the average total variable cost per hectare of coffee cultivation was Rs.27674.22 whereas average per hectare total return from coffee cultivation was Rs.84550.39. The cost of production per $\mathrm{kg}$ of fresh fruit berries was Rs.9.82. The average per hectare gross margin was Rs.56876.17 which indicates that coffee cultivation was profitable in the study area. These findings were similar in line of Pandit (2008). Benefit cost ratio was 3.05 which indicates that coffee cultivation was a prominently profitable enterprise. Profitability index was 2.05, which indicating that coffee farmers in the study area earned Rs.2.05 on each rupee invested in production process. These results are similar with the results of Acharya and Dhakal (2014) and Sharma et al. (2016).

\section{Amortized cost and returns of coffee plantation}

Amortized cost and returns of coffee plantation is presented in Table 3. The table 3 revealed that the anticipated marginal net revenue was more than amortized net revenue (year 1-25, economic life), indicating that it is profitable to continue with the existing plantation.

In conclusion, Paderu division coffee has a great potentiality at domestic and international market because it covers arakuvally area plantations. Coffee plantation was labour intensive plantations, directly generates employment and income to local tribal people. Benefit cost ratio of 3.05 indicates coffee cultivation was prominently profitable enterprise. Profitability index of 2.05 indicates that farmers earned Rs.2.05 on each rupee invested on coffee production in the study area showed that coffee cultivation is suitable enterprises for income generation. There is no revenue during the first three years because the coffee starts producing from fourth year. Revenue starts to climb steeply from fifth year and continue to increase annually until $15^{\text {th }}$ year after which it slowly decline due to the age of plant. Amortized cost and returns of coffee plantation revealed that the anticipated marginal net revenue was more than amortized net revenue indicating that it is profitable to continue with the existing plantation.

\section{References}

Acharya, B and Dhakal, S.C. 2014. Profitability and major problems of coffee production in palpa district, Nepal. International Journal of Applied Sciences and Biotechnology. 2 (4) :460463.

Bajracharya, P. 2003. Business Plan for HCPC Limited, AEC/FNCCI. Katmandu. Nepal. Coffee Promotion Project.(2007). Coffee promotion programme annual report. Helvetas Nepal, Bakhundole, Lalitpur, Nepal.

Deepika, M.G and Jyotishi, A. 2013. Assessing risk and risk mitigation strategies of small coffee growers: a study of kodagu district in Karnataka. NRPPD Discussion Paper 21.

Erhabor, P.O and Olukosi, J.A. 1988. Introduction to Farm Management Principles and Application. Zaria. Agitab Publisher. 47.

Indian coffee. Magazine November. 2015.

Kattel, R.R. 2009. The impact of coffee production on nepali smallholders in the coffee value chain. M. Sc. Thesis submitted to Institute for Environmental Economics and World Trade, Leibniz University Hannover, Germany.

Kumbharj, S., Pawarp, P., Patoles, D and Gavalia, S. 2014. Economics of production and marketing of guava in Maharashtra. International journal of agricultural sciences. 10: 592-599. 
Noormahayu, M.N., Khalid, A.R and Elsadig, M.A. 2009. Financial assessment of oil palm cultivation on peatland in Selangor, Malaysia. International Mire Conservation Group and International Peat Society.5: 1-18.

Pandit, J. 2008. Export potentiality of organic coffee production in Nepal. Unpublished thesis. Tribhuvan University. Institute of Agriculture and Animal Science, Rampur, Chitwan, Nepal.

Poudel, K.L., Nepal, A.P., Dhungana, B., Sugimoto, Y., Yamamoto, $\mathrm{N}$ and
Nishiwaki, A. 2009. Capital budgeting analysis of organic coffee production in Gulmi district of Nepal. International Association of Agricultural Economists conference, Beijing, China.1-13.

Sharma, S., Dhakal, C.K., Ghimire, B and Rijal, A. 2016. Economic significance of coffee (coffee arabica) production in parbat district of nepal. International Journal of Agricultural Management and Development. 6(2): 123-130.

Upendranadh, 2010. Coffee Conundrum: Whither the Future of Small Growers in India,' NRPPD Discussion Paper.

\section{How to cite this article:}

Satish Kumar, C.H., K. Solmon Raju Paul, K. Umadevi and Umar, S.K.N. 2019. Cost and Returns of Coffee Cultivation in Visakhapatnam District of Andhra Pradesh, India. Int.J.Curr.Microbiol.App.Sci. 8(09): 453-460. doi: https://doi.org/10.20546/ijcmas.2019.809.055 